\title{
Sciendo
}

DOI: 10.2478 /aucts-2019-0009

ACTA UNIVERSITATIS CIBINIENSIS - TECHNICAL SERIES

Vol. $71 \quad 2019$

\section{EXPERIMENTAL TESTING OF SOME POLYMER MATERIALS}

\author{
MUNTEAN Diana \\ Faculty of Engineering / Department of Industrial Engineerig, "Lucian Blaga" University of Sibiu, \\ Romania,diana.muntean@ulbsibiu.ro \\ OLEKSIK Mihaela \\ Faculty of Engineering/Department of Engineering and Management, "Lucian Blaga" University of \\ Sibiu, Romania, mihaelaa.oleksik@ulbsibiu.ro \\ BOLOGA Octavian \\ Faculty of Engineering/Department of Industrial Engineerig, "Lucian Blaga" University of Sibiu, \\ Romania,diana.muntean@ulbsibiu.ro
}

\begin{abstract}
The research aims to test polymer materials as the plastic materials: UHMWPE and POM, to observe there characteristics, to determing how they can be used and what we can obtain from them. We wanted to see the strong and the weak values that characterize them, what kind of parts we can produce from them and in what case we can use it. By applying this tests is necessary in order to see real datas that can help you compare them, and lead you to conclusions. Using these methods of testing materials leads to the establishment of real properties of the material and to the establishment of new configurations necessary to be made to the manufactured parts.
\end{abstract}

Key words: tensile test, polymer materials, plastic materials

\section{Introduction}

In this paper we tried to compare the result of testing two composite materials used in the machine building industry, one is UHMWPE (ultrahigh-molecular-weight polyethylene) an the other one is POM (Polyoxymethylene). The UHMWPE is a polietilen that differentiates by other polymers due to the molecular chains that are very long and resistant. The POM is a polymer with a high level of crystallinity, ranking among the hardest and most rigid technical plastic.

\section{Traction machine}

The traction machine testing, with who we do the tests is an electromechanical testing system, a Instron machine Series 5587, placed in the laboratory of University "Lucian Blaga" from Sibiu. The traction test machine, Instron 5587, includes an extensometer with the calibrated length about $50 \mathrm{~mm}$, who has the possibility of mounting by the elongation direction of specimen that causes the local specific deformation using a measuring optic system called Aramis, created by the Gom company. [1] Using this machine, we assay after calibrate the system 12 specimens, from every material tested to determined there deformation at different speeds. In our traction test we used an European standard dimension for specimens apply for traction test, SR EN 1002-1:2002, so the specimen dimensions are: $20 \mathrm{~mm}$ wide, $160 \mathrm{~mm}$ long and $3 \mathrm{~mm}$ thickness. 


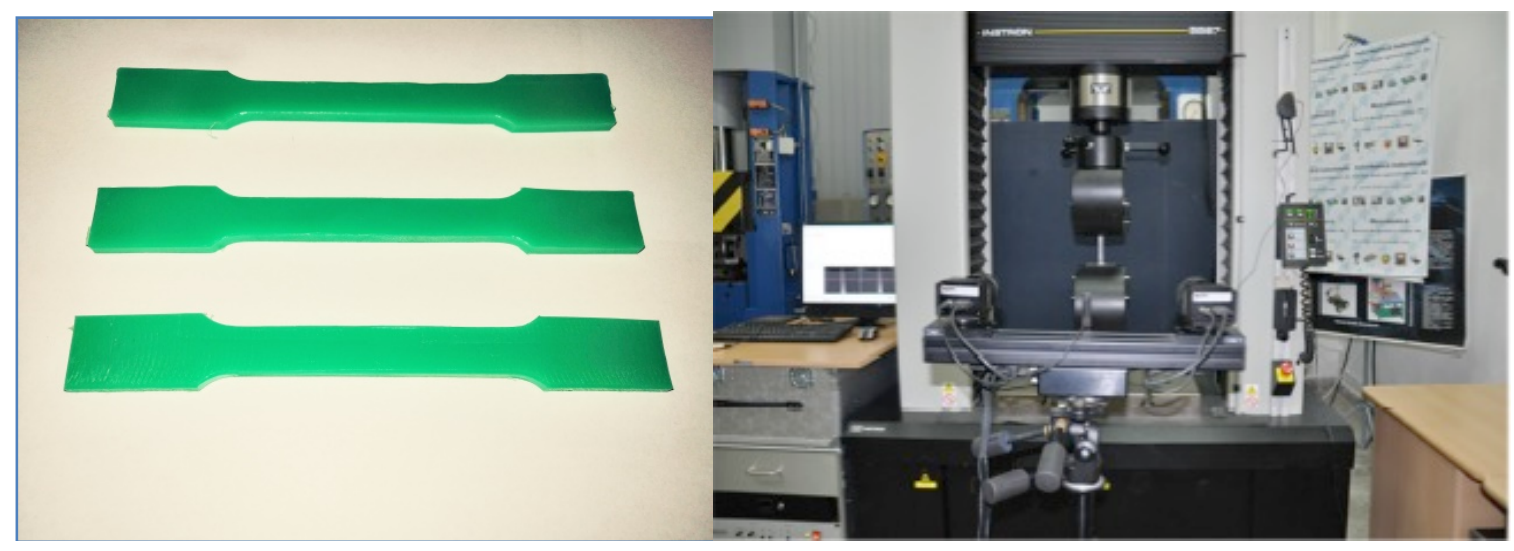

Figure 1: Specimens tested

This system offers the possibility of measuring in real time the deformations appeared in the test specimen at the uniaxial traction. In tension testing, the test specimen is held securely in the jaws of upper and lower grips of the traction machine. [2]

\section{Samples of UHMWPE}

UHMW (ultra high molecular weight polyethylene) is a composite material, an extremely tough plastic with high abrasion and wear resistance. The versatility of this polyethylene has made it a popular plastic for countless industrial applications that need durability, low friction, and chemical resistance. [3]

The modulus of elasticity taken into account is the one determined on the basis of the traction curve. Traction materials were tested at three different speeds: $10 \mathrm{~m} / \mathrm{s}, 50 \mathrm{~m} / \mathrm{s}$ and $100 \mathrm{~m} / \mathrm{s}$. The first tested material was the UHMWPE composite material, and down below we can see the curve resulted by the tensile strain and tensile stress. We tested three samples for each speed.

This material has very good rigidity, tenacity and amortization properties, frazzle resistance and is low welding. Generaly this type of material is used in mechanical applications. [4] The material we choose is used in engineering industry, in flexible manufacturing lines, where positioning platforms for car body and special conveyer for the moving car body exist, they are called conveyance station from a work station to another. [5]

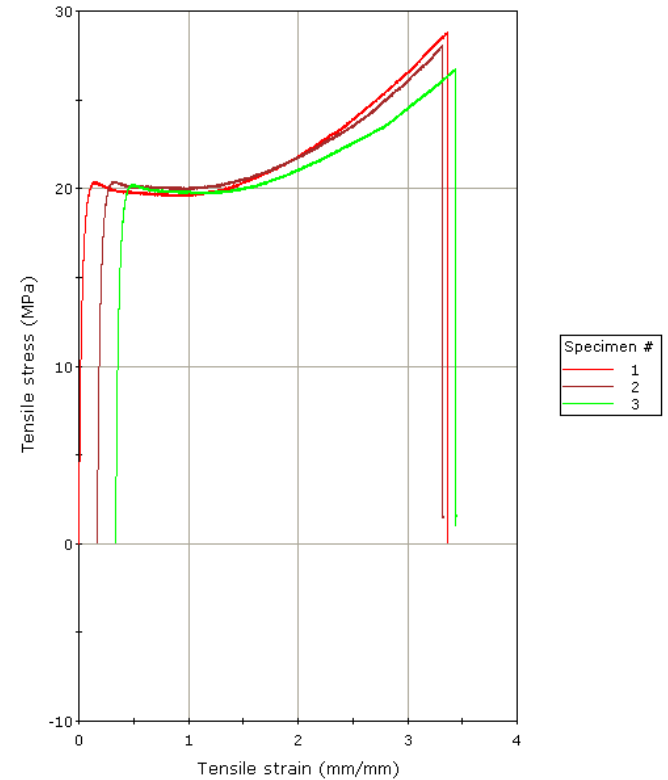

Figure 3: Tensile stress / Elongation at traction speed $10 \mathrm{~mm} / \mathrm{s}$

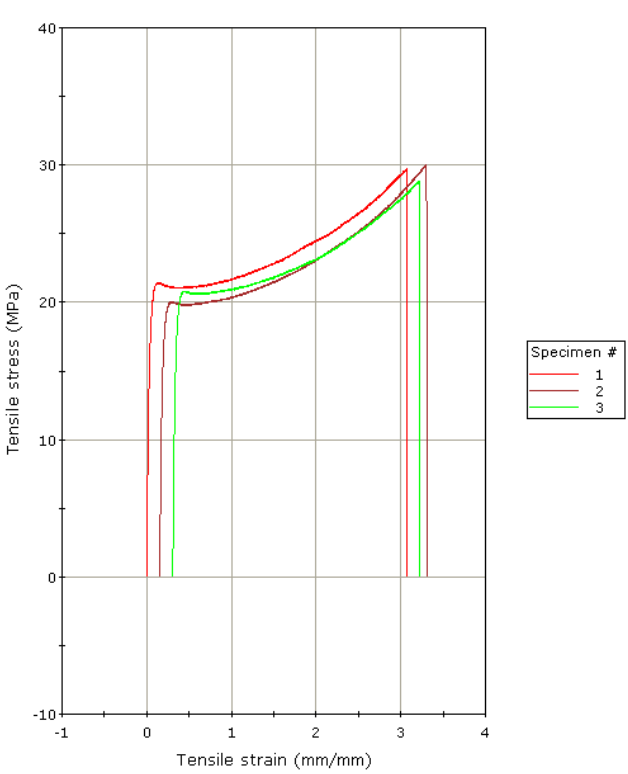

Figure 4: Tensile stress / Elongation at traction speed $50 \mathrm{~mm} / \mathrm{s}$ 


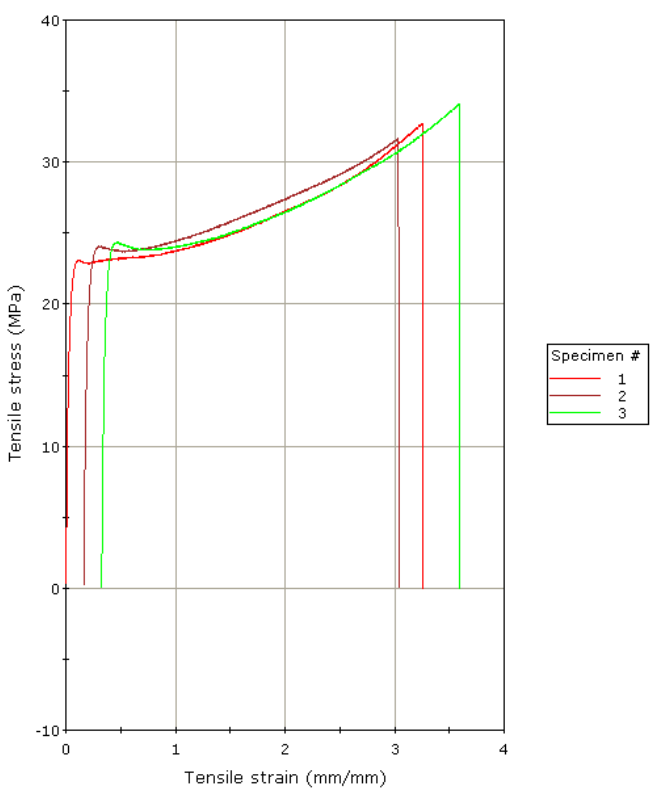

Figure 5: Tensile stress / Elongation at traction speed $100 \mathrm{~mm} / \mathrm{s}$

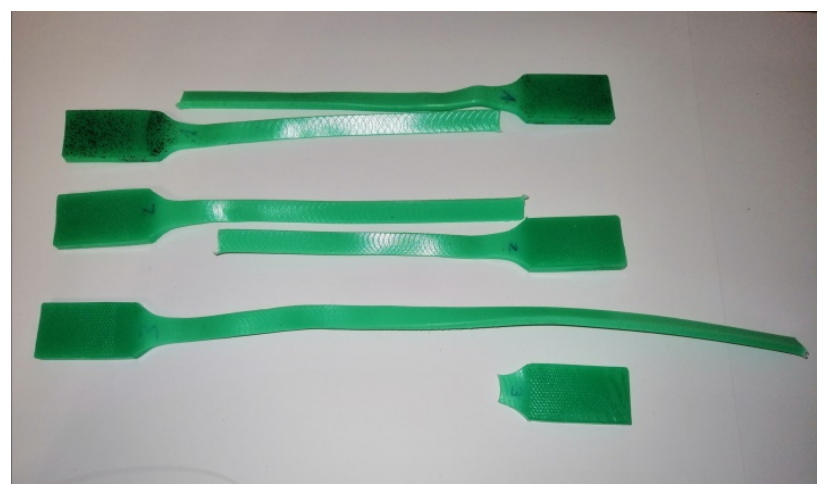

Figure 6: Tensile test specimens at speed $10 \mathrm{~mm} / \mathrm{s}$

From the analysis of the variation graphs tensile stress - tensile strain for the UHMWPE material, it is observed that after reaching the yield stress, the tension increases continuously on a relatively full slope until reaching the maximum value where the first rupture cracks appear.

Table 1: Machine testing results

\begin{tabular}{|c|c|c|c|c|c|c|c|c|c|c|}
\hline UHMWPE & $\begin{array}{c}\text { Nr. } \\
\text { specimen }\end{array}$ & $\begin{array}{c}\text { Modulus } \\
\text { (MPa) }\end{array}$ & $\begin{array}{c}\text { Maximum } \\
\text { Tensile } \\
\text { stress } \\
\text { (MPa) }\end{array}$ & $\begin{array}{c}\text { Tensile } \\
\text { strain at } \\
\text { Maximum } \\
\text { Tensile } \\
\text { stress (\%) }\end{array}$ & $\begin{array}{c}\text { Load at } \\
\text { Maximum } \\
\text { Tensile } \\
\text { stress (N) }\end{array}$ & $\begin{array}{c}\text { Extention } \\
\text { at } \\
\text { Maximum } \\
\text { Tensile } \\
\text { stress } \\
\text { (mm) }\end{array}$ & $\begin{array}{c}\text { Tensile } \\
\text { strain at } \\
\text { Break } \\
(\mathrm{mm} / \mathrm{mm})\end{array}$ & $\begin{array}{c}\text { Tensile } \\
\text { stress } \\
\text { at } \\
\text { Break } \\
\text { (MPa) }\end{array}$ & $\begin{array}{c}\text { Tensile } \\
\text { strain at } \\
\text { Yield } \\
(\mathrm{mm} / \mathbf{m m})\end{array}$ & $\begin{array}{c}\text { Tensile } \\
\text { strain } \\
\text { at } \\
\text { Yield } \\
\text { (MPA) }\end{array}$ \\
\hline \multirow{3}{*}{$\begin{array}{c}\text { Speed } \\
10 \mathrm{~mm} / \mathrm{s}\end{array}$} & 1 & 477.838 & 28.780 & 336.240 & $1,726.851$ & 302.616 & 3.362 & 15.796 & 0.862 & 19.549 \\
\hline & 2 & 433.557 & 28.078 & 314.629 & $1,684.729$ & 283.166 & 3.161 & 1.558 & 0.738 & 19.937 \\
\hline & 3 & 451.028 & 26.743 & 309.666 & $1,604.633$ & 278.699 & 3.108 & 1.567 & 0.876 & 19.701 \\
\hline \multicolumn{2}{|c|}{ Average } & 454.141 & 27.867 & 320.178 & 1,672.071 & 288.160 & 3.210 & 6.307 & 0.825 & 19.729 \\
\hline \multirow{3}{*}{$\begin{array}{c}\text { Speed } \\
50 \mathrm{~mm} / \mathrm{s}\end{array}$} & 1 & 538.125 & 29.735 & 307.314 & $1,784.102$ & 276.583 & 3.074 & 28.967 & 0.366 & 0.366 \\
\hline & 2 & 497.447 & 30.043 & 314.537 & $1,802.581$ & 283.083 & 3.150 & 24.752 & 0.354 & 0.354 \\
\hline & 3 & 507.397 & 28.789 & 290.092 & $1,727.350$ & 261.083 & 2.907 & 28.786 & 0.297 & 0.297 \\
\hline \multicolumn{2}{|c|}{ Average } & 514.323 & 29.522 & 303.981 & $1,771.344$ & 273.583 & 3.044 & 27.501 & 0.339 & 0.339 \\
\hline \multirow{3}{*}{$\begin{array}{c}\text { Speed } \\
100 \mathrm{~mm} / \mathrm{s}\end{array}$} & 1 & 661.161 & 32.742 & 325.370 & $1,964.549$ & 292.833 & 3.253 & 32.742 & 0.198 & 0.198 \\
\hline & 2 & 602.299 & 31.665 & 287.037 & $1,899.931$ & 258.333 & 2.874 & 19.415 & 0.353 & 0.353 \\
\hline & 3 & 564.914 & 34.050 & 326.481 & $2,043.052$ & 293.833 & 3.268 & 19.692 & 0.438 & 0.438 \\
\hline \multicolumn{2}{|c|}{ Average } & 609.458 & 32.819 & 312.962 & $1,969.177$ & 281.666 & 3.131 & 23.949 & 0.329 & 0.329 \\
\hline
\end{tabular}

The centralizing table showes the values of maximum tensile stress, load at maximum tensile stress, extention at maximum tensile stress, tensile strain at break, tensile stress at break and tensile strain at Yield, for the UHMWPE samples.

\section{Samples of POM}

POM (polyoxymethlylene) is an thermoplastic material, which has good fatigue resistance and high impact strength, and can replace parts made of $\mathrm{Cu}, \mathrm{Zn}$, iron casting and stainless steel, and it is 
used in the automobile industry or in the electronic appliance industry. [6]

The second material which we tested is a POM material. Traction materials were tested at three different speeds: $10 \mathrm{~mm} / \mathrm{s}, 50 \mathrm{~mm} / \mathrm{s}$ and $100 \mathrm{~mm} / \mathrm{s}$. The samples are a POM composite material, and down below we can see the curve resulted by the tensile strain and tensile stress. We tested three samples for each speed.

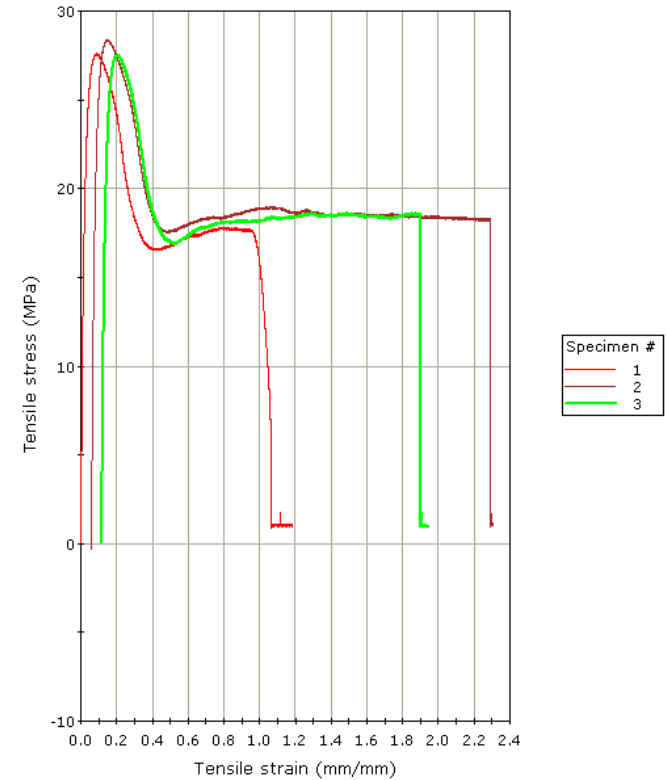

Figure 7: Tensile stress / Elongation at traction speed $10 \mathrm{~mm} / \mathrm{s}$

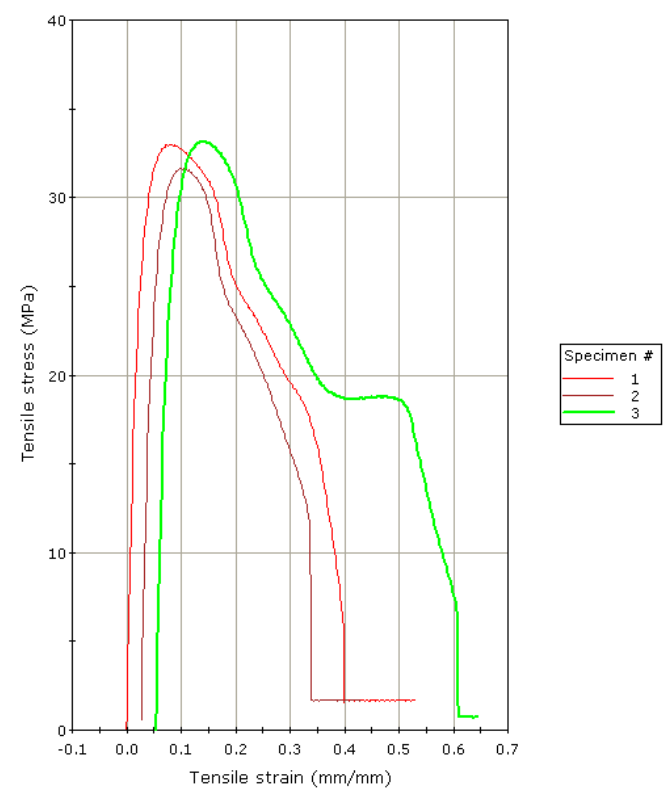

Figure 9: Tensile stress / Elongation at traction speed $100 \mathrm{~mm} / \mathrm{s}$

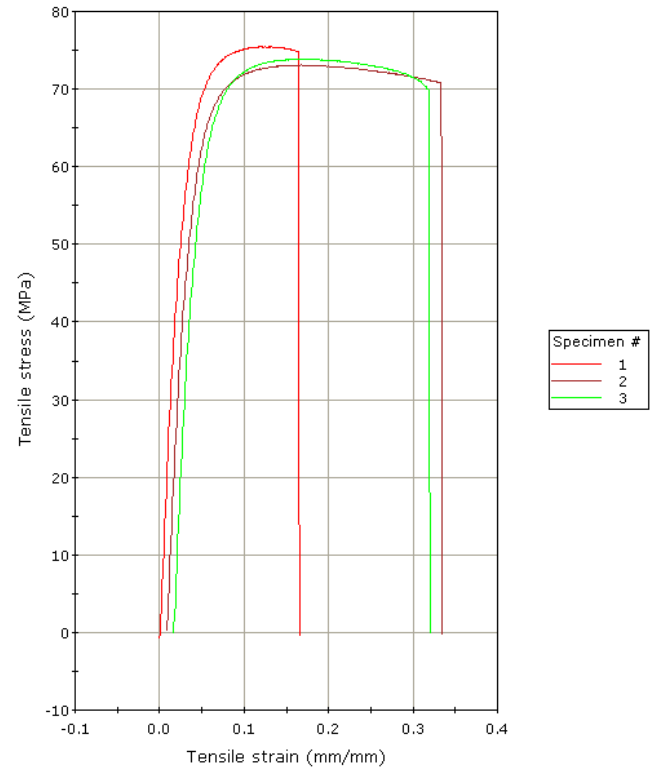

Figure 8: Tensile stress / Elongation at traction speed $50 \mathrm{~mm} / \mathrm{s}$

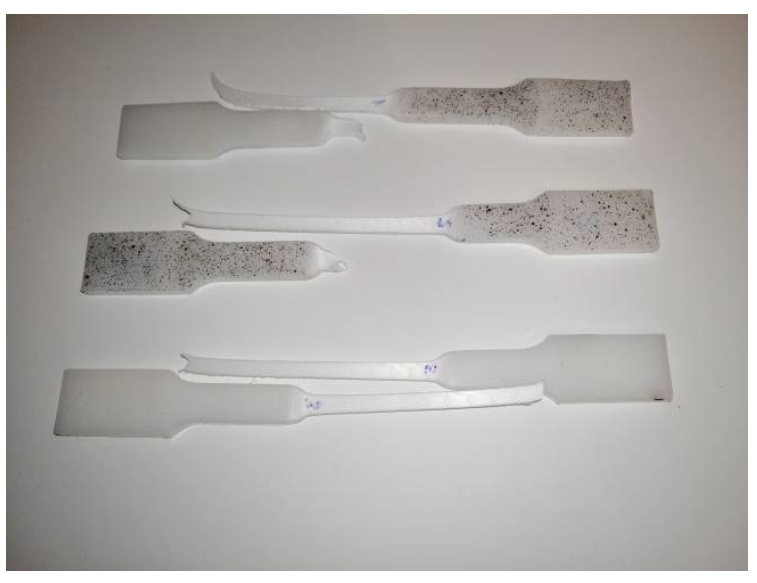

Figure 10: Tensile test specimens at speed $10 \mathrm{~mm} / \mathrm{s}$

From the analysis of the variation graphs tensile stress - tensile strain for the POM material at a speed of $10 \mathrm{~mm} / \mathrm{s}$, it is observed that after reaching the yield stress the tension decreases sharply by about $1 / 3$, after which it remains approximately constant until the moment of rupture. For the same type of material at a speed of $50 \mathrm{~mm} / \mathrm{s}$, after reaching yield stress, the tention decreases slowly, until the rupture occurs. For the same type of material, at $100 \mathrm{~mm} / \mathrm{s}$, after reaching yield stress, the tension decreases continuously until the rupture occurs. 
Table: 2 Machine testing results

\begin{tabular}{|c|c|c|c|c|c|c|c|c|c|c|}
\hline POM & $\begin{array}{c}\text { Nr. } \\
\text { specimen }\end{array}$ & $\begin{array}{c}\text { Modulus } \\
\text { (MPa) }\end{array}$ & $\begin{array}{c}\text { Maximum } \\
\text { Tensile } \\
\text { stress } \\
\text { (MPa) }\end{array}$ & $\begin{array}{c}\text { Tensile } \\
\text { strain at } \\
\text { Maximum } \\
\text { Tensile } \\
\text { stress (\%) }\end{array}$ & $\begin{array}{c}\text { Load at } \\
\text { Maximum } \\
\text { Tensile } \\
\text { stress (N) }\end{array}$ & $\begin{array}{c}\text { Extention } \\
\text { at } \\
\text { Maximum } \\
\text { Tensile } \\
\text { stress } \\
\text { (mm) }\end{array}$ & $\begin{array}{c}\text { Tensile } \\
\text { strain at } \\
\text { Break } \\
(\mathrm{mm} / \mathrm{mm})\end{array}$ & $\begin{array}{c}\text { Tensile } \\
\text { stress } \\
\text { at } \\
\text { Break } \\
\text { (MPa) }\end{array}$ & $\begin{array}{c}\text { Tensile } \\
\text { strain at } \\
\text { Yield } \\
(\mathbf{m m} / \mathbf{m m})\end{array}$ & $\begin{array}{c}\text { Tensile } \\
\text { strain } \\
\text { at } \\
\text { Yield } \\
\text { (MPA) }\end{array}$ \\
\hline \multirow{3}{*}{$\begin{array}{c}\text { Speed } \\
10 \mathrm{~mm} / \mathrm{s}\end{array}$} & 1 & $1,000.118$ & 27.605 & 8.685 & $1,656.350$ & 7.816 & 1.181 & 1.007 & 0.427 & 16.520 \\
\hline & 2 & $1,022.633$ & 28.387 & 9.111 & $1,703.277$ & 8.199 & 2.246 & 1.037 & 0.432 & 17.511 \\
\hline & 3 & 969.014 & 27.550 & 9.166 & $1,653.002$ & 8.250 & 1.824 & 1.039 & 0.411 & 16.855 \\
\hline \multicolumn{2}{|c|}{ Average } & 997.255 & 27.847 & 8.987 & $1,670.876$ & 8.088 & 1.750 & 1.027 & 0.423 & 16.962 \\
\hline \multirow{3}{*}{$\begin{array}{c}\text { Speed } \\
50 \mathrm{~mm} / \mathrm{s}\end{array}$} & 1 & $2,214.159$ & 75.464 & 11.944 & $4,527.847$ & 10.749 & 0.164 & 74.819 & $\begin{array}{l}---- \\
-\end{array}$ & $\begin{array}{l}---- \\
-\cdots\end{array}$ \\
\hline & 2 & $1,875.064$ & 73.100 & 15.925 & $4,386.049$ & 14.333 & 0.325 & 70.828 & ----- & ---- \\
\hline & 3 & $1,891.778$ & 73.868 & 16.111 & $4,432.132$ & 14.499 & 0.302 & 69.674 & ----- & ---- \\
\hline \multicolumn{2}{|c|}{ Average } & $1,993.667$ & 74.144 & 14,660 & $4,448.676$ & 13.193 & 0.263 & 71,773 & ----- & ----- \\
\hline \multirow{3}{*}{$\begin{array}{c}\text { Speed } \\
100 \mathrm{~mm} / \mathrm{s}\end{array}$} & 1 & $1,289.013$ & 32.977 & 8.146 & $1,978.655$ & 7.331 & 0.531 & 1.725 & 0.400 & 1.589 \\
\hline & 2 & $1,293.816$ & 31.645 & 7.219 & $1,898.711$ & 6.497 & 0.404 & 1.720 & 0.325 & 1.604 \\
\hline & 3 & $1,172.765$ & 33.152 & 8.702 & $1,989.154$ & 7.832 & 0.590 & 0.707 & 0.353 & 18.623 \\
\hline \multicolumn{2}{|c|}{ Average } & $1,251.864$ & 32.591 & 8.022 & $1,955.506$ & 7.220 & 0.508 & 1.384 & 0.359 & 21.816 \\
\hline
\end{tabular}

The centralizing table shows the values of maximum tensile stress, load at maximum tensile stress, extention at maximum tensile stress, tensile strain at break, tensile stress at break and tensile strain at Yield, for the POM samples.

After seeing the values from the centralizing tables, we used a chart to establish the modulus, the maximum tensile stress and the extention at maximum tensile stress at the three speeds we tested the POM material.

\section{Conclusions}

After seeing the values from the centralizing tables, we used a chart to establish the Maximum Tensile stress for UHMWPE and the Maximum Tensile stress for POM, at the three speeds we tested the specimens.

Tab1e 3: Comparation between Maximum Tensile stress of UHMWPE and POM

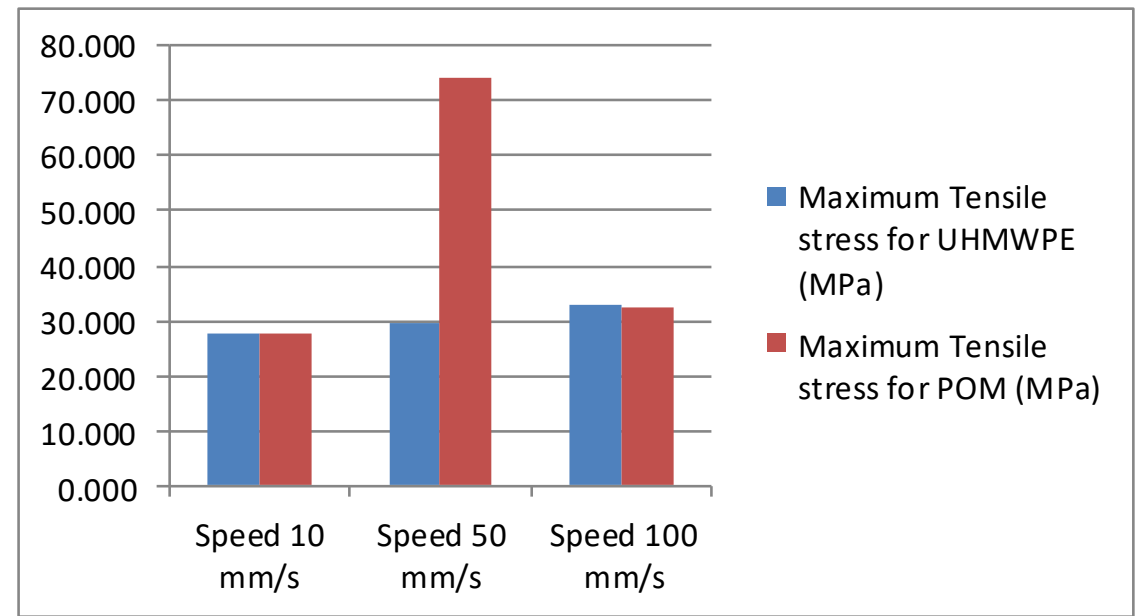

The results of the tensile tests at the three test speeds for the UHMWPE material lead to the following conclusions: the modulus of elasticity increases with the increase of the test speed, as well as Maximum Tensile stresses, and Extension at Maximum Tensile stress has values close to a slight 
decrease at valued speed of $50 \mathrm{~mm} / \mathrm{s}$.

The results of the tensile tests at the three test speeds for the POM material lead to the following conclusions: the modulus of elasticity has a maximum value at the speed of $50 \mathrm{~mm} / \mathrm{s}$ $(1,993.667 \mathrm{MPA})$, the next immediate value being is at $100 \mathrm{~mm} / \mathrm{s}(1,251.864 \mathrm{MPA})$ and the most smallest value is obtained at a speed of $10 \mathrm{~mm} / \mathrm{s}$ (997.255 MPA). The same variation model has Maximum Tensile stress and Extention at Maximum Tensile stress.

From the analysis of these graphs we can conclude that the test speed influences not only the value of the Maximum Tensile stress, Extention at Maximum Tensile stress but also the shape of the test graphs. In conclusion, the material POM is much more influenced by the test speed than the UHMWPE.

\section{Bibliography}

[1] Mihaela Oleksik, "Cercetări teoretice și experimentale privind comportarea mecanică a materialelor compozite cu suport textil," Thesis, p. 133, (2014).

[2] Instron, "Reference Manual - Equipment," www.instron.com, (2005).

[3] C. Plastics, "www.curbellplastics.com," [Online]. [Accessed 14 November 2019].

[4] Neagoe Fluoropolimeri, "Poliamida", "www.ptfe.ro," [Online]. [Accessed 6 November 2019].

[5] Diana Muntean, Octavian Bologa, "From part to point cloud, the modelling of a 3D part," p. 2, (2019).

[6] H. Li, W.Z. Zhang, "Application research of modified POM three layers composite," J.Beijing Univ. Chem. Technol. 27, (2000). 